\title{
Pengaruh Kompensasi, Lingkungan Kerja Dan Penghargaan Atas Prestasi Kerja Terhadap Kinerja Karyawan Di PT. Asuransi ASEI Indonesia Unit Syariah Cabang Pekanbaru
}

\author{
Jeli Nata Liyas \\ Sekolah Tinggi Ilmu Ekonomi Riau
}

\begin{abstract}
The purpose of this research is to know the influence of compensation, work environment and reward for high performance against the performance of employees at PT. Asuransi Asei Indonesia Unit Syariah cabang Pekanbaru. Analysis of data used is the analysis of the regression of the linear risks. The sample of this study as many as 55 of the respondents who is a permanent employee at PT. Asuransi Asei Indonesia Unit Syariah cabang Pekanbaru. Variables are used is compensation, work environment and reward for high performance. The results showed that these three variables tested simultaneously have a significant effect on the performance of employee at PT. Asuransi ASEI Indonesia Unit Syariah cabang Pekanbaru. In partial compensation significantly influences, while the work environment and reward for high performance does not affect the significant. Variables are compensation, work environment and reward for high performance of influential $79 \%$ of employee performance, while the rest of the $21 \%$ affected by variables not included in research.
\end{abstract}

Keywords: compensation, work environment, reward for high performance, employee performance.

\section{Pendahuluan}

Menghadapi arus globalisasi di abad-21 seperti saat ini dengan persaingan dunia kerja yang semakin kompetitif, maka perusahaan dituntut untuk mempunyai keunggulan bersaing bukan hanya kualitas produk semata tetapi memiliki sumber daya manusia yang professional. Sumber daya manusia yang berkualitas merupakan asset yang sangat penting bagi perusahaan. Peranan sumber daya manusia dalam perusahaan juga menentukan keberhasilan atau kegagalan suatu kebijaksanaan, strategi, maupun langkah-langkah kegiatan operasional yang dilaksanakan dalam perusahaan. Manusia adalah sumber daya yang paling penting keberadaannya dalam perusahaan, karena ditangan manusialah segala aktivitas yang berhubungan dengan kegiatan perusahaan diambil. Canggihnya teknologi 
yang digunakan tanpa didukung oleh sumber daya manusia yang handal juga tidak akan mampu menghasilkan output yang sesuai dengan tingkat efisiensi yang diinginkan dalam perusahaan, karena betapa pun modernnya peralatan serta mesinmesin yang digunakan akan tetapi unsur manusia masih tetap memegang peranan yang sangat menentukan.

Keadaan ini menjadikan sumber daya manusia sebagai salah satu unsur penentu keberhasilan perusahaan yang harus ditingkatkan efisiensi dan kinerjanya. Sumber daya manusia yang dikelola dengan baik akan memberikan kinerja yang baik pula dalam organisasi atau perusahaan. Pengelolaan sumber daya manusia memiliki peran penting dalam suatu organisasi perusahaan. Maksudnya dengan pengelolaan sumber daya manusia yang baik akan meningkatkan kinerja karyawan. Setiap perusahaan mengharapkan kinerja karyawan yang tinggi. Kualitas dan kuantitas menunjukkan potensi seseorang untuk melakukan pekerjaan atau tugas yang diberikan. Bila karyawan mampu bekerja untuk kualitas yang prima dan kuantitas yang maksimal, maka perusahaan akan menjadi semakin efektif dalam operasionalnya. Namun kenyataan yang terjadi di PT. Asuransi Asei Indonesia Unit Syariah Cabang Pekanbaru adalah masih terdapat banyak sekali permasalahanpermasalahan didalamnya ditinjau dari segi kualitas, kuantitas, ketepatan waktu, efektifitas serta komitmen kerja.

Asuransi pada awalnya adalah suatu kelompok yang bertujuan membentuk arisan untuk meringankan beban keuangan individu dan menghidari kesulitan pembiayaan. Secara umum konsep asuransi merupakan persiapan yang dibuat oleh sekelompok orang yang masing-masing menghadapi kerugian kecil sebagai suatu yang tidak dapat diduga. Menurut Wirjono (1987) asuransi sebagai persetujuan yang didalamnya terdapat perjanjian dari pihak yang menjamin kepada pihak yang dijamin, untuk menerima sejumlah uang premi sebagai pengganti kerugian yang memungkin akan diderita oleh yang dijamin, karena akibat dari peristiwa yang belum jelas.

Menurut Departemen PT Asuransi Syariah Takaful Keluarga (1994) Perkembangan asuransi syariah di Indonesia baru ada pada paruh akhir tahun 1994,yaitu dengan berdirinya Asuransi Tafakul Indonesia pada tanggal 25 Agustus 
1994, dengan diresmikannya PT Asuransi Takaful Keluarga melalui SK Menkue NO.Kep-385/KMK.017/1994. Islam mengajarkan pemeluknya untuk merencanakan dan mempersiapkan hari esok untuk lebih baik mengingat kehidupan di dunia yang penuh dengan resiko (Ridlwan, 2016). Praktik asuransi syariah merupakan jawaban atas kebutuhan kaum muslim dalam mengantisipasi kemungkinan terjadinya resiko secara islami. Asuransi syariah dengan penerapan prinsip dasar yang tidak bertentangan dengan syariah syariat islam memiliki kemaslahatan yang lebih banyak untuk semua umat, tidak hanya umat muslim semata. Menurut M. Nur Rianto (2012) Asuransi Syariah memiliki beberapa ciri Utama :

a) Akad Asuransi Syariah bersifat Tabarru

b) Akad asuransi syariah ini bukan akad mulzim (Perjanjian yang wajib dilaksanakan) bagi kedua belah pihak.

c) Dalam asuransi syariah tidak ada pihak yang lebih kuat karena semua keputusan dan aturan diambil menurut izin jamaah, seperti dalam asuransi Takaful

d) Akad asuransi syariah bersih dari maysir, gharar, dan riba

e) Asuransi syariah bernuasa kekeluargaan.

f) Pada perusahaan asuransi Syariah (ta'min, takaful, atau tadhamum), hubungan kerjasama antara kedua blah pihak akan terjadi jika transaksi dilakukan berdasarkan akad mudharabah, yang bertujuan untuk melindungi tertanggung dari resiko keuangan masa depan yang tidak terduga (Billah, 1998). Peranan perusahaan hanya sebagai pengelola dana asuransi syariah yang dibayarkan oleh nasabah asuransi syariah dalam bentuk premi asuransi syariah dengan menggunakan akad mudaharabah, dan pengelola dana sebagai mudharib, sedangkan pemegang polis premi asuransi sebagai peserta polis asuransi syariah atau shahibul maal merupakan pemilik dana sepenuhnya (Billah, 1998).

g) Perusahaan melakukan bisnis dengan tujuan agar tercapai laba atau profit yang maksimal, apabila perusahaan telah membuat sebuah produk dengan 
nilai yang bersaing di pasaran, kemudian membuat sebuah strategi pemasaran yang tepat dengan melakukan segmentasi pasar, diharapkan pada akhirnya produk tersebut memberikan sumbangan besar dalam perolehan laba akhir tahun perusahaan asuransi syariah.

h) Oleh karena itu, penelitian hendak menganalisis sistem pembayaran premi pada PT. Asuransi Takaful Keluarga dalam asuransi syariah yaitu. 1) bagaimana model penghitungan tarif premi untuk produk saving dan non saving pada perusahaan asuransi syariah 2) bagaimana penentuan segmentasi pasar berdasarkan produk yang ditawarkan khusus untuk perusahaan asuransi syariah. 3) bagaimana keterkaitan antara jenis produk yang ditawarkan untuk segmen pasar tertentu dengan besarnya profit perusahaan asuransi syariah.

Adapun tujuan dari penelitian ini ialah 1) menjelaskan model penghitungan tarif premi khusus untuk produk saving dan non saving pada perusahaan asuransi syariah 2) Menjelaskan segmentasi pasar yang tepat untuk produk yang ditawarkan perusahaan asuransi syariah 3) menjelaskan hubungan antara jenis produk asuransi dan segmentasi pasar dengan besarnya profit perusahaan asuransi syariah.

Karyawan PT. Asuransi Asei Indonesia Unit Syariah Cabang Pekanbaru belum bekerja secara optimal ini terbukti dalam bekerja karyawan sering melakukan kesalahan dalam menginput jumlah premi asuransi sehingga terjadi komplain terhadap kesalahan tersebut, ini juga mengakibatkan pemborosan dalam pemakaian kertas karena karyawan bekerja secara berulang-ulang dan hasilnya tidak efektif dan efisien. Karyawan juga sering terlambat/tidak tepat waktu untuk mengantarkan proposal polis sehingga pembayaran pun tersendat-sendat dibayar oleh konsumen.

Karyawan tidak serius dalam bekerja, sering malas-malasan, sering tidak masuk kerja, sering keluar kantor untuk melakukan kegiatan-kegiatan pribadi yang tidak ada hubungannya dengan kepentingan perusahaan, tidak memiliki komitmen kerja, mengulur-ulur waktu serta tidak menyelesaikan pekerjaan sesuai dengan ketepatan waktu yang ada. Waktu yang seharusnya dimanfaatkan untuk bekerja, tetapi karyawan mempergunakannya untuk keluar ruangan, makan, ngobrol dengan 
sesama rekan kerja. Sebagai perusahaan yang bergerak dibidang jasa maka karyawan PT. Asuransi Asei Indonesia Unit Syariah Cabang Pekanbaru harus memberikan pelayanan terbaik bagi para konsumen. Keberhasilan dalam memberikan pelayanan kepada para konsumen ditentukan oleh penilaian terhadap kinerja karyawannya. Penilaian tersebut tidak hanya dilakukan untuk mengawasi sumber daya perusahaan tetapi juga untuk mengukur tingkat efisiensi penggunaan sumber daya yang ada serta mengidentifikasi hal-hal yang perlu diperbaiki. Penilaian terhadap kinerja merupakan faktor yang sangat penting untuk meningkatkan kinerja karyawan. Faktor yang paling menarik dikaji atau diteliti dari variabel kinerja adalah kualitas dan kuantitas kerja karyawan.

Kualitas kerja berarti karyawan memiliki mind set, keterampilan, pengetahuan dan niat baik untuk bekerja secara berkualitas, rapi, bersih, teliti dan indah. Kualitas kerja dan kuantitas kerja sangat tergantung kepada niat dan kemauan karyawan untuk berprestasi. Jika karyawan memiliki kemampuan untuk menjadikan dirinya sebagai pribadi yang produktif, maka tentunya karyawan akan memfokuskan diri untuk kualitas dan kuantitas kerja yang prima. Kualitas kerja merupakan salah satu unsur yang di evaluasi dalam menilai kinerja karyawan. Kualitas kerja dapat diukur melalui ketepatan, kelengkapan dan kerapian. Yang dimaksud dengan ketepatan adalah ketepatan dalam menjalankan tugas dan pekerjaan, artinya terdapat kesesuaian antara rencana kegiatan dengan sasaran atau tujuan yang telah ditetapkan. Yang dimaksud dengan kelengkapan adalah ketelitian dalam melaksanakan pekerjaan. Yang dimaksud dengan kerapian adalah kerapian dalam melaksanakan tugas dan pekerjaan.

Kuantitas kerja berarti karyawan harus berupaya dengan sekuat tenaga untuk mencapai hasil kerja yang sesuai dengan target, artinya karyawan harus selalu menyiapkan kondisi tubuh yang sehat dan penuh semangat, kondisi pikiran yang tenang dan kreatif. Dalam memberikan pelayanan teknis terhadap pelanggan/penyewa seperti penggantian alat-alat yang rusak yang harus segera diselesaikan, tetapi karyawan lambat dalam penanganannya. Bahwa karyawan PT. Asuransi Asei Indonesia Unit Syariah Cabang Pekanbaru belum bekerja secara 
professional yang mengakibatkan menurunnya kinerja karyawan. Terjadinya penurunan kinerja karyawan juga dapat disebabkan karena kompensasi yang diterima belum sesuai dengan yang diharapkan. Ada karyawan yang sudah bekerja selama bertahun-tahun namun dalam pemberian kompensasi terdapat perbedaan dan ditemukan adanya ketidak adilan dalam tunjangan.

Selain kompensasi, lingkungan kerja juga sangat mempengaruhi kinerja karyawan. Masih adanya suasana kerja yang kurang menyenangkan, dimana terjadinya pengelompokan-pengelompokan dalam unit kerja. Seperti karyawan yang hanya ingin bergaul dengan karyawan yang lebih dikenalnya saja, tidak bebas bergaul dengan karyawan lainnya. Perenggangan hubungan seperti ini dapat menimbulkan perselisihan sehingga lingkungan kerja akan menjadi tidak nyaman. Dengan demikian karyawan merasa lingkungan yang tidak menyenangkan tentunya berpengaruh terhadap sikap dan kualitas layanannya sehingga karyawan tidak bisa bekerja secara maksimal. Perusahaan memberikan penghargaan atas prestasi kerja terhadap karyawan ini dimaksudkan agar dalam bekerja karyawan tersebut dapat bekerja secara maksimal sehingga karyawan tersebut loyal terhadap perusahaan. Tetapi di PT. Asuransi Asei Indonesia Unit Syariah Cabang Pekanbaru masih banyak karyawan yang sudah bekerja selama puluhan tahun namun, posisi pekerjaannya tidak berubah dan tidak mengalami peningkatan dalam jenjang karier padahal karyawan tersebut sudah senior. Kondisi yang monoton seperti ini mengakibatkan kejenuhan pada karyawan sehingga mempengaruhi kinerja karyawan. Peneliti tertarik untuk melakukan penelitian di Perusahaan PT. Asuransi Asei Indonesia Unit Syariah Cabang Pekanbaru karena adanya penurunan kinerja sehingga memperlambat produktivitas serta tujuan perusahaan.

Penelitian ini dilakukan untuk mengetahui apakah kompensasi, lingkungan kerja dan penghargaan atas prestasi kerja mempunyai pengaruh yang signifikan terhadap kinerja karyawan. Membenahi setiap kelemahan yang ada atau kendala yang membuat kinerja itu berkurang, maka perusahaan perlu memperhatikan faktor-faktor yang dapat mempengaruhi kinerja karyawan. Setelah mengetahui faktor-faktor tersebut, perusahaan bisa meningkatkan kinerja karyawan agar dapat bekerja secara optimal dan efisien. Berdasarkan latar belakang masalah tersebut 
inilah yang mendorong peneliti memilih kinerja karyawan sebagai bahan penelitian. Peneliti tertarik untuk melakukan penelitian dengan judul : "Pengaruh Kompensasi, Lingkungan Kerja dan Penghargaan Atas Prestasi Kerja Terhadap Kinerja Karyawan di PT. Asuransi Asei Indonesia Unit Syariah Cabang Pekanbaru”.

\section{Tinjauan pustaka}

\section{Kompensasi}

Menurut Veithzal Rivai (2005:456) mendapatkan kompensasi yang adil adalah : mendapatkan imbalan yang sesuai dengan tingkat pendidikan karyawan dan kesesuaian gaji standar kerja dengan beban tugas yang diberikan. Semakin tinggi tingkat pendidikan karyawan, maka semakin tinggi pula kemungkinan karyawan tersebut melakukan perbandingan social dengan karyawan yang lain. Jika gaji yang diberikan perusahaan lebih rendah, maka akan timbul ketidakpuasan kerja karyawan terhadap gaji yang diberikan. Gaji harus ditentukan sedemikian rupa agar antara kedua belah pihak (karyawan dan perusahaan) merasa sama-sama di untungkan. Dengan demikian karyawan yang merasa puas dengan gaji yang diterimanya akan dapat menciptakan kepuasan kerja sehingga berpengaruh pada kinerja karyawan.

Menurut Malayu S. P. Hasibuan (2003:118) "Gaji adalah balas jasa yang dibayar secara periodik kepada karyawan tetap serta mempunyai jaminan pasti. Gaji akan tetap dibayarkan walaupun pekerja tidak masuk kerja". Menurut Hariandja dalam Maretta (2005:136) mendefenisikan kompensasi sebagai pembayaran serta balas jasa yang diberikan kepada pegawai, tata usaha dan manajer sebagai konsekuensi dari sumbangan yang diberikannya dalam pencapaian tujuan perusahaan.

\section{Lingkungan kerja}

Menurut Veithzal Rivai (2005:456) lingkungan kerja yang menyenangkan adalah lingkungan kerja yang mendukung dan sesuai dengan jenis pekerjaannya sehingga karyawan bisa melaksanakan kerja atau tugas dengan baik, karena bekerja di dalam lingkungan yang mendukung dan menyenangkan. Lingkungan kerja dalam suatu perusahaan sangat penting untuk diperhatikan oleh pihak perusahaan. Penataan 
serta penyusunan suatu sistem produksi yang baik tidak akan dapat dilaksanakan dengan efektif bila tidak didukung oleh lingkungan tempat kerja yang baik dan kondusif. Menurut Anwar Prabu Mangkunegara (2005:17) lingkungan kerja yang dimaksud antara lain uraian jabatan yang jelas, target kerja yang menantang, pola komunikasi kerja yang efektif, iklim kerja dan fasilitas kerja yang relative memadai. Selanjutnya Sedarmayanti (2001:21) menyatakan bahwa secara garis besar, jenis lingkungan kerja terbagi menjadi dua yakni :

1) Lingkungan kerja fisik diantaranya adalah : penerangan/cahaya, temperatur/suhu udara, kelembaban, sirkulasi udara, kebisingan, setaran mekanis, bau tidak sedap, tata warna, dekorasi, musik dan keamanan di tempat kerja.

2) Lingkungan kerja non fisik diantaranya adalah hubungan sosial di tempat kerja baik antara atasan dengan bawahan atau hubungan antara sesama karyawan.

\section{Penghargaan Atas Prestasi Kerja}

Menurut Veithzal Rivai (2005:456) penghargaan adalah : hadiah atas prestasi yang dilakukan oleh karyawan kepada perusahaan, sehingga membuat karyawan merasa dihargai. Menurut Nawawi (2005:319), "reward adalah usaha menumbuhkan perasaan diterima (diakui) di lingkungan kerja, yang menyentuh aspek kompensasi dan aspek hubungan antara para pekerja yang satu dengan yang lainnya". Manajer mengevaluasi hasil kinerja individu baik secara formal maupun informal. Penghargaan adalah ganjaran yang diberikan untuk memotivasi para karyawan agar produktivitasnya tinggi (Tohardi, 2002:317). Penghargaan adalah insentif yang mengaitkan bayaran atas dasar untuk dapat meningkatkan produktivitas para karyawan guna mencapai keunggulan yang kompetitif (Henry Simamora, 2004:514). Dengan adanya pendapat para ahli diatas maka penulis dapat menyimpulkan bahwa suatu penghargaan adalah imbalan yang diberikan dalam bentuk material dan non material yang diberikan oleh pihak perusahaan kepada karyawannya agar mereka dapat bekerja dengan motivasi yang tinggi dan berprestasi dalam mencapai tujuan-tujuan perusahaan, dengan kata lain pemberian penghargaan dimaksudkan untuk meningkatkan produktivitas dan mempertahankan karyawan yang berprestasi agar tetap berada dalam perusahaan. 


\section{Kinerja Karyawan}

Kinerja karyawan (Simamora, 2004:83) adalah tingkat hasil kerja karyawan dalam pencapaian persyaratan pekerjaan yang diberikan. Berdasarkan dua pendapat diatas maka dapat diambil suatu pengertian bahwa kinerja dalam pengertian umum adalah tercapainya apa yang telah ditetapkan atau digariskan sebagai tujuan atau sasaran. Hal ini sesuai dengan pendapat yang menyatakan apa yang kita maksud dengan kinerja adalah pencapaian. Selanjutnya untuk membahas pengertian kerja dapat dilihat dari beberapa segi, antara lain dikemukakan Kartono (2004:2) bahwa : "Kerja merupakan aktivitas dasar dan bagian esensial dari kehidupan manusia, sama halnya aktivitas bermain anak-anak, maka kerja akan memberikan kesenangan dalam arti tersendiri dari kehidupan. Sebab kerja itu memperbaiki status pada seseorang yang mengakibatkan diri sendiri dengan individu-individu lain dalam masyarakat".

Lebih lanjut menurut (Prawirosentono, 2008:23), kinerja adalah hasil kerja yang dapat dicapai oleh seseorang atau sekelompok orang dalam satu organisasi, sesuai dengan wewenang dan tanggung jawab masing-masing, dalam rangka mencapai tujuan organisasi yang bersangkutan secara legal, tidak melanggar hukum dan sesuai dengan moral dan etika.

Dengan demikian pengertian kerja adalah : rangkaian aktivitas yang dilaksanakan oleh manusia didalam melaksanakan aktivitas tersebut terdapat cara yang secara sadar maupun tidak cara tersebut ditentukan oleh manusia pelaksana kerja untuk tujuan yang telah ditentukan sebelumnya. Berdasarkan uraian tentang kinerja dan pengertian kerja yang ada, maka jika pengertian tersebut digabungkan akan diperoleh suatu pengertian kerja. Menurut Siagian (2008:183) kinerja adalah : penyelesaian pekerjaan tepat pada waktu yang telah ditetapkan atau dapat dikatakan apakah pelaksanaan sesuai yang direncanakan. Artinya apakah pelaksanaan tergantung pada bilamana itu diselesaikan dan tidak menjawab pertanyaan, bagaimana melaksanakannya dan berapa biaya yang dikeluarkan itu. 


\section{Hubungan Antar Variabel}

\section{Pengaruh Kompensasi Terhadap Kinerja Karyawan}

Menurut Veithzal Rivai (2005:456) mendapatkan kompensasi yang adil adalah : mendapatkan imbalan yang sesuai dengan tingkat pendidikan karyawan dan kesesuaian gaji standar kerja dengan beban tugas yang diberikan. Menurut Robbins (2001:149) bahwa para karyawan menginginkan sistem upah dan kebijakan promosi yang mereka persepsikan sebagai adil, tidak meragukan, dan segaris dengan pengharapan mereka. Bila upah dilihat sebagai adil yang didasarkan pada tuntutan pekerjaan, tingkat ketrampilan individu, dan standar pengupahan komunitas, kemungkinan besar akan dihasilkan kepuasan”. Tingkat pendidikan yang tinggi dapat membuat karyawan melakukan perbandingan sosial dengan karyawan yang lain, sehingga jika perusahaan memberikan gaji yang rendah maka akan menimbulkan ketidakpuasan kerja karyawan terhadap gaji. Oleh karena itu perusahaan harus menentukan gaji yang sedemikian rupa agar diantara kedua belah pihak (karyawan dan perusahaan) akan merasa sama-sama diuntungkan. Karena jika karyawan merasa puas dengan gaji yang diterimanya, maka dapat menciptakan kepuasan kerja yang diharapkan berpengaruh pada kinerja karyawan.

\section{Pengaruh Lingkungan Kerja Terhadap Kinerja Karyawan}

Menurut Veithzal Rivai (2005:456) lingkungan kerja yang menyenangkan adalah : lingkungan kerja yang sesuai dengan keinginan karyawan untuk melaksanakan kerja atau tugas dengan baik sehingga karyawan bekerja dengan lingkungan yang menyenangkan. Seorang pegawai yang bekerja didalam suatu organisasi, mau tidak mau akan dipengaruhi oleh lingkungan kerjanya. Lingkungan kerja pegawai dapat bermacam-macam keadaannya. Ada lingkungan kerja yang menyenangkan, sehingga pegawai dapat bekerja dengan tenang dan dalam tingkat produktivitas yang tinggi. Menurut pendapat Agus Ahyari (2002:122) bahwa : "lingkungan kerja yang memuaskan bagi karyawan perusahaan yang bersangkutan akan dapat meningkatkan gairah kerja di dalam perusahaan yang bersangkutan tersebut. Lingkungan kerja yang cukup memuaskan para karyawan perusahaan akan mendorong para karyawan tersebut untuk bekerja dengan sebaik-baiknya, sehingga pelaksanaan proses produksi di dalam perusahaan tersebut akan dapat 
berjalan dengan baik pula".

Pengaruh Penghargaan Atas Prestasi Kerja Terhadap Kinerja Karyawan

Menurut Veithzal Rivai (2005:456) penghargaan adalah : hadiah/reward atas prestasi yang dilakukan oleh karyawan kepada perusahaan, sehingga membuat karyawan merasa dihargai. Penghargaan adalah ganjaran yang diberikan untuk memotivasi para karyawan agar produktivitasnya tinggi (Tohardi, 2002:317). Penghargaan adalah insentif yang mengaitkan bayaran atas dasar untuk dapat meningkatkan produktivitas para karyawan guna mencapai keunggulan yang kompetitif (Henry Simamora, 2004:514). Dengan adanya pendapat para ahli diatas maka peneliti dapat menyimpulkan bahwa suatu penghargaan adalah imbalan yang diberikan dalam bentuk material dan non material yang diberikan oleh pihak perusahaan kepada karyawannya agar mereka dapat bekerja dengan baik serta berprestasi dalam mencapai tujuan-tujuan perusahaan, dengan kata lain pemberian penghargaan dimaksudkan untuk meningkatkan produktivitas dan mempertahankan karyawan yang berprestasi agar tetap. Pemberian sistem penghargaan dimaksudkan sebagai dorongan agar karyawan mau bekerja dengan lebih baik dan mendorong kinerja karyawan menjadi lebih baik.

\section{Hipotesis}

Hipotesis merupakan dugaan sementara yang mungkin benar dan mungkin salah, sehingga dapat dianggap atau dipandang sebagai konsklusi atau kesimpulan yang sifatnya sementara, sedangkan penolakan atau penerimaan suatu hipotesis tersebut tergantung dari hasil penelitian terhadap faktor-faktor yang dikumpulkan, kemudian diambil suatu kesimpulan.

$\mathrm{H} 1$ = Kompensasi berpengaruh signifikan terhadap Kinerja Karyawan di PT. Asuransi Asei Indonesia Unit Syariah Cabang Pekanbaru H2 = Lingkungan Kerja berpengaruh signifikan terhadap Kinerja Karyawan di PT. Asuransi Asei Indonesia Unit Syariah Cabang Pekanbaru H3 = Penghargaan Atas Prestasi Kerja berpengaruh signifikan terhadap Kinerja Karyawan di PT. Asuransi Asei Indonesia Unit Syariah Cabang Pekanbaru. 


\section{Metode penelitian}

\section{Populasi dan Sampel}

Populasi dalam penelitian ini adalah seluruh karyawan tetap di PT. Asuransi Asei Indonesia Unit Syariah Cabang Pekanbaru yang berjumlah 55 orang. Dari populasi diatas maka diambil 55 karyawan dengan metode sensus. Sensus adalah pengumpulan data dengan mengambil elemen atau anggota populasi secara keseluruhan untuk diselidiki. Data yang diperoleh dari hasil sensus disebut parameter atau data yang sebenarnya. Sudijono (2009: 28 ) mengatakan keuntungan menggunakan sensus yaitu hasil yang diperoleh merupakan nilai karakteristik yang sebenarnya, karena sasaran penelitian mencakup objek yang ada di dalam populasi.

\section{Metode Analisis Data}

Menurut Sugiyono (2012) analisis data merupakan kegiatan setelah data dari seluruh sumber terkumpul menggunakan statistik. Supaya data yang telah dikumpulkan tersebut dapat bermanfaat, maka harus diolah dan dianalisis terlebih dahulu sehingga dapat dijadikan sebagai dasar dalam pengambilan keputusan. Dalam menganalisis data, peneliti menggunakan analisa deskriptif kuantitatif yaitu data - data yang diperoleh akan dikumpulkan lalu ditarbulasikan menurut kriterianya. Selanjutnya akan disajikan dalam bentuk tabel dengan uraian dan penjelasan secara terperinci dengan data teori yang berhubungan dengan penelitian.

\section{Analisis Hipotesis}

\section{Uji Asumsi Klasik}

Uji Asumsi Klasik dilakukan untuk mengetahui apakah model regressi yang dibuat dapat digunakan sebagai alat prediksi yang baik. Uji asumsi klasik yang akan dilakukan adalah uji normalitas, uji multikolinearitas, Uji Auto korelasi, dan uji heteroskedastisitas. Pada saat penelitian dengan menggunakan analisis regresi berganda, maka penguji perlu melakukan ujia sumsi klasik agar pendugaan tidak bias.

a) Uji Normalitas

Menurut Ghozali (2013) mengemukakan bahwa: “Uji normalitas bertujuan untuk mengetahui apakah masing-masing variabel berdistribusi normal atau tidak. 
Uji normalitas diperlukan karena untuk melakukan pengujian-pengujian variabel lainnya dengan mengansumsikan bahwa nilai residual mengikuti distribusi normal. Untuk menguji suatu data berdistribusi normal atau tidak, dapat diketahui dengan menggunakan grafik normal plot. Dengan melihat histogram dari residualnya. Dasar penambil keputusan (Ghozali, 2011):

1) Jika data menyebar disekitar garis diagonal dan mengikuti arah garis diagonal atau grafik histogramnya menunjukkan pola distribusi normal, maka model regresi memenuh asumsi normalitas.

2) Jika data menyebar jauh dari diagonal dan tidak mengikuti arah garis diagonal atau grafik histogram tidak menunjukkan pola distribusi normal, maka model regresi tidak memenuhi asumsi normalitas. Uji normalitas dalam penelitian ini menggunakan metode Kolmogrov Smirnov jika hasil angka signifikansi (Sig) lebih kecil dari 0,05 maka data tidak terdistribusi normal.

b) Uji Multikolinearitas

Uji Multikolinearitas dimaksudkan untuk membuktikan atau menguji ada atau tidaknya hubungan yang linier (multikolinearitas) antara variabel bebas (independen) satu dengan variabel bebas yang lain. Pengujian multikolinearitas dilakukan dengan melihat hasil dari nilai tolerance di atas 10 persen atau 0,1 dan nilai Variance Inflation Factor (VIF) di bawah 10 yang berarti tidak terdapat gejala multikolinearitas (Utama, 2014).

c) Uji Autokorelasi

Uji Autokorelasi digunakan untuk mengetahui ada atau tidaknya penyimpangan asumsi klasik autokorelasi yaitu korelasi yang terjadi antara residual pada satu pengamatan dengan pengamatan lain pada model regresi. Prasyarat yang harus terpenuhi adalah tidak adanya autokorelasi dalam model regresi. Metode pengujian yang sering digunakan adalah dengan uji Durbinwatson (Uji DW) dengan ketentuan sebagai berikut (Santoso, 2012):

1. Bila nilai D-W terletak dibawah -2 berarti ada autokorelasi positif

2. Bila nilai D-W terletak diantara -2 sampai +2 berarti tidak ada autokorelasi.

3. Bila nilai D-W terletak diatas +2 berarti ada autokorelasi negatif. 
d) Uji Heteroskedastisitas

Uji heteroskedastisitas bertujuan untuk menguji apakah dalam model regresi terjadi ketidaksamaan varian dari satu pengamatan ke pengamatan yang lain (Ghozali, 2007). Cara mendeteksinya adalah dengan melihat ada tidaknya pola tertentu pada grafik scatterplot antara SRESID dan ZPRED, dimana sumbu Y adalah $\mathrm{Y}$ yang telah diprediksi, dan sumbu $\mathrm{X}$ adalah residual ( $\mathrm{Y}$ diprediksi $-\mathrm{Y}$ sesungguhnya) yang telah di - standardized (Ghozali, 2007). Sedangkan dasar pengambilan keputusan untuk uji heteroskedastisitas adalah sebagai berikut:

1) Jika adapola tertentu, sepertititik yang ada membentuk pola tertentu teratur (bergelombang, melebur kemudian menyempit), maka mengindikasikan telah terjadi heteroskedastisitas.

2) Jika tidak adapola yang jelas, sertatitik - titik meyebar diatas dan dibawah angka 0 (nol) pada sumbu Y, maka tidak terjadi heteroskedastisitas.

\section{Analisis Regresi Liniear Berganda}

Analisis data yang digunakan adalah analisa kuantitatif yaitu dengan suatu model untuk mengukur pengaruh tiga (3) faktor terhadap kinerja karyawan digunakan perhitungan secara regresi linier berganda. Untuk pengujian dianggap kinerja karyawan (Y) dipengaruhi oleh tiga (3) faktor . Di sini dapat kita masukkan ke dalam fungsi linier berganda dengan bentuk persamaan (Ghozali, 2005:82)

Dimana :

$$
\mathrm{Y}=\mathrm{a}+\mathrm{b} 1 \mathrm{X} 1+\mathrm{b} 2 \mathrm{X} 2+\mathrm{b} 3 \mathrm{X} 3+\mathrm{e}
$$

Y : kinerja karyawan

a : konstanta

b : koefisien regresi

$\mathrm{X} 1$ : kompensasi

$\mathrm{X} 2$ : lingkungan kerja

X3 : penghargaan atas prestasi kerja

e : error

\section{Uji Hipotesis}

Setelah melakukan pengujian normalitas data dan pengujian asumsi klasik, langkah selanjutnya yaitu melakukan pengujian atas hipotesis 1 (H1) sampai hipotesis 5 (H5). Pengujian tingkat signifikan (Test Of Significance) merupakan suatu prosedur untuk mengetahui dimana hasil sampel digunakan dalam pengujian 
hipotesis. Alat analisis yang dapat digunakan yaitu uji t, uji f dan koefisien determinasi (R2). Perhitungan tersebut signifikan secara statistik apabila berada dalam daerah H0 ditolak. Sebaliknya disebut tidak signifikan jika uji nilai.

\section{Uji t-test}

Untuk menguji tingkat signifikansi dari masing-masing koefisien regresi yang diperoleh dari perhitungan, dilakukan uji t dua sisi yang dapat dirumuskan sebagai berikut :

Ho $: \beta \mathrm{i}=0$ : Variabel independen tidak berpengaruh secara signifikan terhadap Variabel dependen

$\mathrm{Ha}: \beta \mathbf{i} \neq 0 \quad$ : Variabel independen berpengaruh secara signifikan terhadap variabel dependen

Perhitungan t-test digunakan dengan rumus sebagai berikut :

t-hitung $=-\underset{S \beta i}{\beta i}$

Dimana :

$\beta \mathrm{i}=$ koefisien regresi

$\mathrm{S} \beta \mathrm{i}=$ standar of error dari b1

Sementara nilai $\mathrm{t}$-tabel $=\mathrm{t} \alpha / 2$ df $(\mathrm{n}-\mathrm{k})$, dimana $\mathrm{k}$ adalah konstan dan parameter dari parameter yang diestimasi.

Dengan menggunakan derajat keyakinan tertentu, maka jika

1. Apabila t-hitung > t-tabel, maka Ho ditolak, berarti koefisien variabel adalah signifikan

2. Apabila t-hitung < t-tabel, maka Ho diterima, berarti koefisien variabel adalah tidak signifikan

Berdasarkan perhitungan t-test apabila t-test diperoleh lebih besar dari nilai t-tabel, berarti terdapat hubungan yang kuat antara variabel independen terhadap kinerja. Sebaliknya t-test hasil hitungan lebih kecil dibanding nilai t-tabel, maka tidak terdapat hubungan antara variabel independen terhadap kinerja.

\section{Uji F (F-test)}

Untuk mengetahui apakah variabel dependen Y yaitu Kinerja Karyawan dipengaruhi oleh variabel independen $\mathrm{X}$ maka dapat dilakukan dengan analisis of 
variance dan F-test. Dengan menggunakan level of significant $(a)=0,05$ maka dapat diambil kesimpulan berikut :

1. Jika F-hit > F-tab maka hipotesa nol (Ho) ditolak dan hipotesa alternatif (Ha) diterima artinya ada pengaruh terhadap kinerja karyawan.

2. Jika F-hit < F-tab maka hipotesa nol (Ho) diterima dan hipotesa alternatif (Ha) ditolak artinya tidak ada pengaruh terhadap kinerja karyawan.

\section{Koefisien Determinasi (R2)}

Selanjutnya untuk mengetahui besarnya pengaruh secara simultan, dilihat dari koefisien determinan (R2) variabel terikat terhadap variabel bebas, syarat koefisien determinan (R2) dikatakan kuat dan berpengaruh apabila (R2) mendekati angka 1 (satu), dan apabila (R2) mendekati 0 (nol) maka pengaruh variabel bebas terhadap variabel terikat serentak adalah lemah.

\section{Hasil dan Pembahasan}

\section{Hasil Penelitian}

\section{Uji Normalitas}

Uji normalitas bertujuan untuk menguji apakah dalam model regresi, variabel residual memiliki distribusi normal. Model regresi yang baik memiliki distribusi data yang normal atau mendekati normal. Pada normal probability plot, data dikatakan normal jika ada penyebaran titik-titik disekitar garis diagonal dan penyebarannya mengikuti garis diagonal. Jika data menyebar disekitar garis normal dan mengikuti garis normal maka model regresi memenuhi asumsi normalitas (Ghozali, 2007). Untuk lebih jelas dapat dilihat pada gambar 1 berikut:

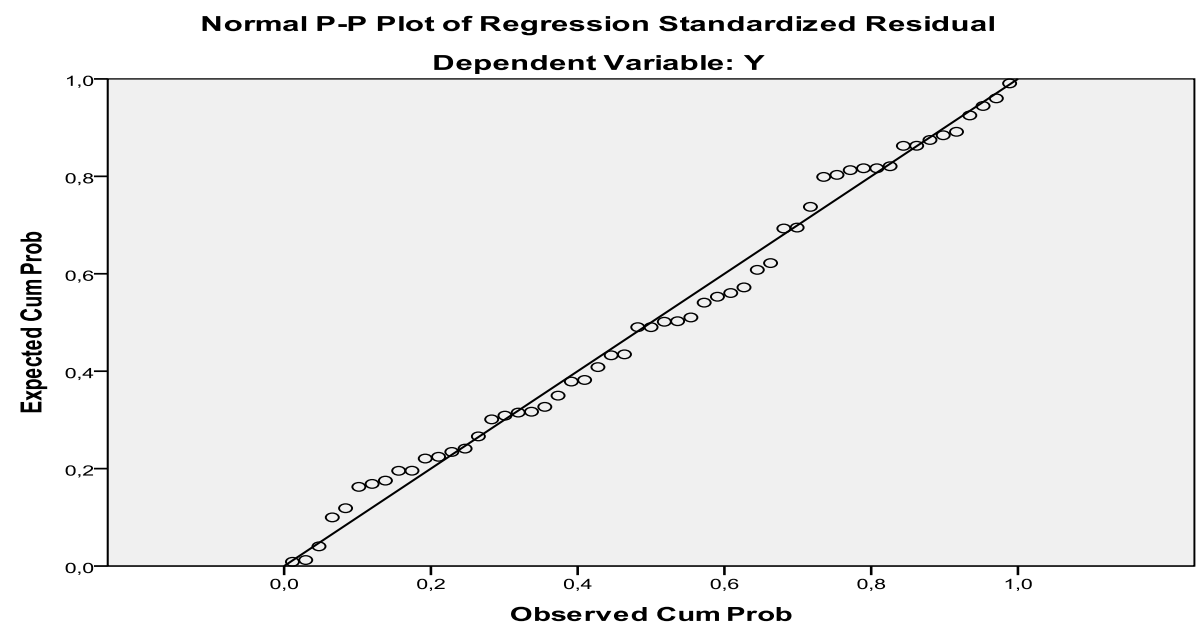




\section{Gambar 1. Hasil Uji Normalitas}

Dari gambar 1 dapat dilihat hasil pengujian tersebut menunjukkan bahwa titik-titik berada tidak jauh dari garis diagonal. Hal ini berarti menunjukkan bahwa model regresi tersebut sudah berdistribusi normal.

\section{Uji Heteroskedastisitas}

Pengujian ini digunakan untuk melihat apakah variabel pengganggu mempunyai varian yang sama atau tidak. Heteroskedastisitas mempunyai suatu keadaan bahwa varian dari residual suatu pengamatan ke pengamatan yang lain berbeda. Pengujian Heteroskedastisitas dilakukan dengan menggunakan grafik Scatterplot. Jika ada pola tertentu, seperti titik-titik yang ada membentuk pola tertentu yang teratur (bergelombang, melebar kemudian menyempit), maka mengindikasikan telah terjadi heteroskedastisitas. Jika tidak ada pola yang jelas, serta titik menyebar di atas dan di bawah angka 0 pada sumbu Y, maka tidak terjadi heteroskedastisitas. Hasil uji heteroskedastisitas adalah sebagai berikut :

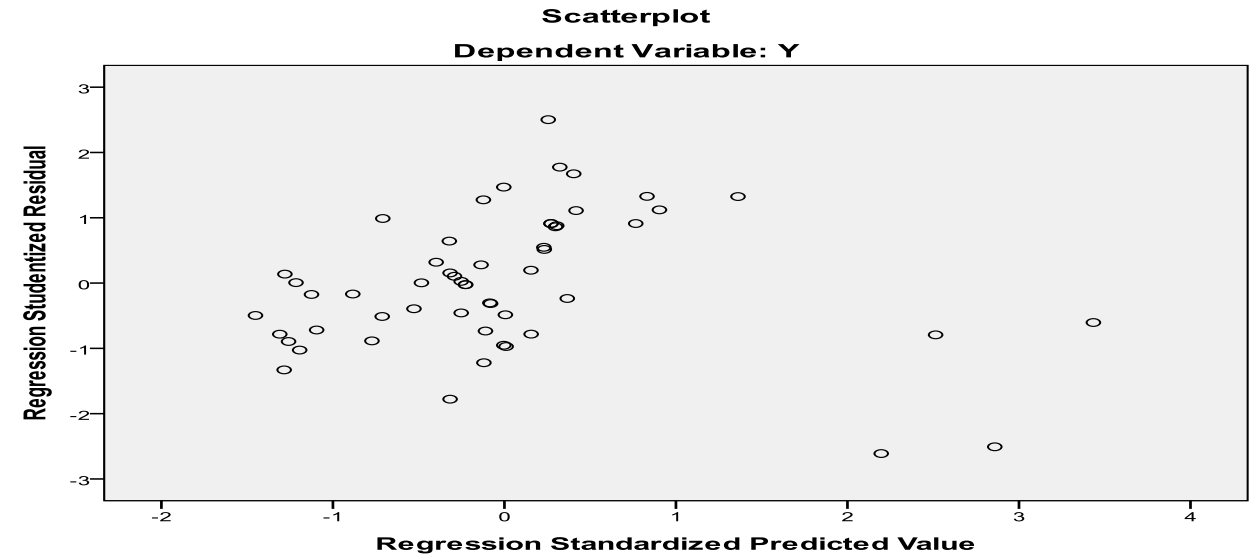

Gambar 2. Hasil Uji Heteroskedastisitas

Sumber: Hasil Penelitian, 2019 (Data Olahan)

Hasil pengujian heteroskedastisitas menunjukkan tidak terdapat pola yang jelas dari titik-titik diatas dan titik-titik tersebut menyebar di atas dan di bawah sumbu Y. Hal ini menunjukkan bahwa model regresi tidak memiliki gejala adanya heteroskedastisitas, yang berarti bahwa tidak ada gangguan dalam model regresi. 


\section{Uji Multikolinieritas}

Uji Multikolinieritas dilakukan untuk memastikan bahwa tidak ada korelasi sempurna antara variabel bebas yang satu dengan variabel bebas lainnya dengan melihat nilai variance inflation factor (VIF). Nilai Tolerance $>0,1$ dan VIF $<10$ maka tidak ada multikolinearitas. Jika nilai tolerance $<0,1$ dan nilai VIF $>10$ menunjukkan adanya gejala multikolinieritas dalam model regresi. Hasi pengujian multikolinieritas diperoleh sebagai berikut:

Tabel 1. Hasil Uji Multikolinieritas

\begin{tabular}{|l|l|l|l|}
\hline Variabel & Tolerance & VIF & Keterangan \\
\hline Kompensasi (X1) & 0,113 & 8,834 & Tidak ada multikolinieritas \\
\hline Lingkungan Kerja (X2) & 0,078 & 12,892 & Ada gejala multikolinieritas \\
\hline $\begin{array}{l}\text { Penghargaan Atas Prestasi Kerja } \\
\text { (X3) }\end{array}$ & 0,382 & 2,621 & Tidak ada multikolinieritas \\
\hline
\end{tabular}

Sumber : Hasil Penelitian, 2019 (Data Olahan)

Hasil pengujian menunjukkan bahwa nilai tolerance X2 <0,1 dan VIF > 10. Ini menunjukkan bahwa variabel X2 ada gejala multikolinearitas. Sedangkan nilai tolerance $\mathrm{X} 1$ dan $\mathrm{X} 3>0,1$ dan VIF $<10$. Ini menunjukkan bahwa variabel X1 dan X3 tidak ada gejala multikolinearitas. Hal ini berarti bahwa variabel-variabel bebas yang digunakan dalam penelitian ini ada yang menunjukkan adanya gejala multikolinieritas dan ada yang tidak menunjukkan gejala multikolinieritas.

\section{Uji Hipotesis}

\section{Analisis Regresi Linier Berganda}

Analisis regresi linear berganda digunakan untuk mengetahui besarnya pengaruh variabel kompensasi, lingkungan kerja dan penghargaan atas prestasi kerja secara parsial maupun simultan terhadap kinerja karyawan.

\section{Uji $\mathbf{t}$}

Uji t digunakan untuk mengetahui pengaruh secara parsial variabel kompensasi, lingkungan kerja dan penghargaan atas prestasi kerja terhadap variabel kinerja karyawan. Berikut akan dijelaskan pengujian masing-masing variabel secara parsial 
Tabel 2. Hasil Uji t

coefficients $^{\mathrm{a}}$

\begin{tabular}{|c|c|c|c|c|c|c|}
\hline \multirow[b]{2}{*}{ Model } & \multicolumn{2}{|c|}{ Unstandardized Coefficients } & \multirow{2}{*}{$\begin{array}{l}\text { Standardized } \\
\text { Coefficients } \\
\text { Beta } \\
\end{array}$} & \multirow[b]{2}{*}{$\mathrm{t}$} & \multirow[b]{2}{*}{ Sig. } & \multirow[t]{2}{*}{ Ket } \\
\hline & B & Std. Error & & & & \\
\hline $\begin{array}{ll}1 & \text { (Constant) }\end{array}$ & 074 & 251 & & 2,294 & ,770 & \\
\hline Kompensasi & ,600 & ,187 &, 594 & 3,202 &, 002 & Sig \\
\hline Lingkungan Kerja & 266 & ,239 &, 250 & 1,114 & ,270 & Tidak Sig \\
\hline Penghargaan Atas Prestasi Kerja &, 105 & ,098 & 109 & 1,077 & 287 & Tidak Sig \\
\hline
\end{tabular}

a. Dependent Variabel:Y

Sumber: Lampiran Hasil 2019

1) Variabel Kompensasi

Ho : Secara parsial kompensasi berpengaruh signifikan terhadap kinerja karyawan.

Ha : Secara parsial kompensasi tidak berpengaruh signifikan terhadap kinerja karyawan.

Berdasarkan hasil pengolahan diperoleh nilai t hitung $(3,202)>t$ tabel $(2,008)$ sehingga hipotesis alternatif (Ha) diterima dan hipotesis nol (Ho) ditolak. Dengan ditolaknya Ho berarti secara parsial Kompensasi berpengaruh secara signifikan terhadap Kinerja Karyawan.

2) Variabel Lingkungan Kerja

Ho : Secara parsial lingkungan kerja tidak berpengaruh signifikan terhadap kinerja karyawan.

Ha: Secara parsial lingkungan kerja berpengaruh signifikan terhadap kinerja karyawan.

Berdasarkan hasil pengolahan data diperoleh nilai $t$ hitung $(1,114)<\mathrm{t}$ tabel $(2,008)$ sehingga hipotesis nol (Ho) diterima dan hipotesis alternatif (Ha) ditolak. Dengan diterimanya Ho berarti secara parsial lingkungan kerja tidak berpengaruh signifikan terhadap Kinerja Karyawan.

3) Variabel Penghargaan Atas Prestasi Kerja

Ho : Secara parsial penghargaan atas prestasi kerja tidak berpengaruh signifikan terhadap kinerja karyawan.

$\mathrm{Ha}$ : Secara parsial penghargaan atas prestasi kerja berpengaruh signifikan terhadap kinerja karyawan. 
Berdasarkan hasil pengolahan diperoleh nilai t hitung $(1,077)<\mathrm{t}$ tabel $(2,008)$ sehingga hipotesa alternatif (Ha) ditolak dan hipotesis nol (Ho) diterima. Dengan ditolaknya $\mathrm{Ha}$ berarti secara parsial penghargaan atas prestasi kerja tidak berpengaruh signifikan terhadap Kinerja Karyawan.

Model persamaan regresi linier berganda yang dapat dituliskan dari hasil tersebut adalah sebagai berikut :

$\mathrm{Y}=0,074+0,600 \mathrm{X1}+0,266 \mathrm{X2}+0,105 \mathrm{X3}$

Pada persamaan tersebut ditunjukan pengaruh variabel independen $(\mathrm{X})$ terhadap variabel dependen (Y). Adapun arti dari koefisien regresi tersebut adalah sebagai berikut :

- Nilai Konstanta (a) sebesar 0,074 : artinya jika kompenssasi, lingkungan kerja dan penghargaan atas prestasi kerja nilainya adalah 0 , maka kinerja karyawan nilainya adalah 0,074 satuan.

- Nilai Koefisien regresi variabel kompensasi sebesar 0,600 : artinya jika variabel independen lain nilainya tetap dan kompensasi mengalami kenaikan 1 satuan, maka kinerja karyawan akan mengalami kenaikan sebesar 0,600 satuan (kenaikan tersebut signifikan). Koefisien bernilai positif artinya semakin tinggi kompensasi yang diberikan maka akan semakin meningkatkan kinerja karyawan.

- Nilai koefisien regresi variabel lingkungan kerja sebesar 0,266 : artinya jika variabel independen lain nilainya tetap dan lingkungan kerja mengalami kenaikan sebesar 0,266 satuan (kenaikan tersebut tidak signifikan). Koefisien bernilai positif artinya terjadi hubungan positif, lingkungan kerja yang baik dan mendukung akan meningkatkan kinerja karyawan.

- Nilai koefisien regresi variabel penghargaan atas prestasi kerja sebesar 0,105 : artinya jika variabel independen lain nilainya tetap dan penghargaan atas prestasi kerja mengalami kenaikan 1 satuan, maka kinerja karyawan akan mengalami kenaikan sebesar 0,105 satuan (kenaikan tersebut tidak signifikan). Koefisien bernilai positif artinya terjadi hubungan positif, penghargaan atas prestasi yang tinggi akan meningkatkan kinerja karyawan. 


\section{Uji F}

Uji F digunakan untuk mengetahui pengaruh secara simultan variabel kompensasi, lingkungan kerja dan penghargaan atas prestasi kerja terhadap variabel kinerja karyawan.

\section{Tabel 3. Hasil Uji F}

\begin{tabular}{|c|c|c|c|c|c|c|}
\hline Model & $\begin{array}{c}\text { Sum of } \\
\text { Squares }\end{array}$ & df & $\begin{array}{c}\text { Mean } \\
\text { Square }\end{array}$ & F & Sig. & Ket \\
\hline Regression & 9,126 & 3 & 3,042 & 68,520 &, $000^{2}$ & Signifikan \\
Residual & 2,264 & 51 &, 044 & & & \\
Total & 11,390 & 54 & & & & \\
\hline
\end{tabular}

Sumber : Lampiran Hasil Uji Statistik, 2019

Ho : Secara bersama-sama variabel kompensasi, lingkungan kerja dan penghargaan atas prestasi kerja tidak berpengaruh signifikan terhadap kinerja karyawan.

Ho : Secara bersama-sama variabel kompensasi, lingkungan kerja dan penghargaan atas prestasi kerja berpengaruh signifikan terhadap kinerja karyawan. Berdasarkan hasil pengujian maka dapat diketahui bahwa nilai $\mathrm{F}$ hitung $(68,520)$ lebih besar $>$ dari F tabel $(2,790)$ sehingga Ho ditolak dan Ha diterima yang berarti secara bersama-sama variabel kompensasi, lingkungan kerja, penghargaan atas prestasi kerja berpengaruh signifikan terhadap kinerja karyawan.

\section{Uji $\mathbf{R}^{2}$ (Koefisien Determinasi)}

Koefisien determinasi digunakan untuk melihat kemampuan variabel independen dalam menerapkan variabel dependen, dimana jika nilai $\mathrm{R}$ square mendekati satu maka variabel independen memberikan semua informasi yang dibutuhkan untuk memprediksi variasi variabel dependen. 
Tabel 4. Koefisien Determinasi

\begin{tabular}{|c|c|c|c|c|}
\hline Model & R & R Square & $\begin{array}{c}\text { Adjusted R } \\
\text { Square }\end{array}$ & $\begin{array}{c}\text { Std. Error of the } \\
\text { Estimate }\end{array}$ \\
\hline 1 &, $895^{\mathrm{a}}$ &, 801 &, 790 &, 21070 \\
\hline \multicolumn{5}{|c}{ a. Predictors (Constant), X3, X1, X2 (C. Dependent Variable; Y } \\
b.
\end{tabular}

Sumber : Lampiran Hasil Uji Statistik, 2019

Dari hasil pengolahan data diketahui bahwa koefisien determinasi (Adjusted $\mathrm{R}$ square) yang diperoleh sebesar 0,790. Hal ini berarti $79 \%$ kinerja karyawan dapat dijelaskan oleh variabel kompensasi, lingkungan kerja dan penghargaan atas prestasi kerja, sedangkan sisanya $21 \%$ kinerja karyawan dipengaruhi oleh variabelvariabel lainnya yang tidak diteliti dalam penelitian ini. Hal ini menunjukkan adanya pengaruh dari kompensasi, lingkungan kerja dan penghargaan atas prestasi kerja terhadap kinerja karyawan di PT. Asuransi Asei Indonesia Unit Syariah Cabang Pekanbaru.

\section{Pembahasan Hasil Penelitian}

Sebagaimana yang telah diuraikan sebelumnya bahwa penelitian ini adalah untuk mengetahui pengaruh kompensasi, lingkungan kerja dan penghargaan atas prestasi kerja terhadap kinerja karyawan di PT. Asuransi Asei Indonesia Unit Syariah Cabang Pekanbaru. Dengan demikian pembahasan yang dilakukan adalah untuk melihat signifikansi kontribusi pengaruh kompensasi, lingkungan kerja dan penghargaan atas prestasi kerja terhadap kinerja karyawan.

Adapun hasil pengujian regresi dan korelasi secara keseluruhan dari model penelitian ini adalah sebagai berikut : Tabel 4.14 Pembahasan Hasil Penelitian

Tabel 5. Pembahasan Hasil Penelitian

\begin{tabular}{|l|l|l|l|}
\hline Hipotesis & Uji F/t & Sig. & Keputusan \\
\hline $\begin{array}{l}\text { Kompensasi, Lingkungan Kerja } \\
\text { dan Pengharghaan Atas Prestasi } \\
\text { Kerja terhadap Kinerja Karyawan }\end{array}$ & 68,520 & 0,000 & Diterima \\
\hline $\begin{array}{l}\text { Kompensasi berpengaruh terhadap } \\
\text { Kinerja Karyawan }\end{array}$ & 3,202 & 0,002 & Diterima \\
\hline $\begin{array}{l}\text { Lingkungan Kerja berpengaruh } \\
\text { terhadap Kinerja Karyawan }\end{array}$ & 1,114 & 0,270 & Ditolak \\
\hline $\begin{array}{l}\text { Penghargaan Atas Prestasi Kerja } \\
\text { berpengaruh terhadap Kinerja } \\
\text { Karyawan }\end{array}$ & 1,077 & 0,287 & Ditolak \\
\hline
\end{tabular}

Sumber : Data Olahan, 2019 


\section{Pengaruh Kompensasi terhadap Kinerja Karyawan}

Dari hasil analisis secara deskriptif, menunjukkan bahwa Kompensasi merupakan faktor yang dianggap baik oleh responden dalam kinerja karyawan. Hasil analisis regresi dan pengujian secara parsial (uji t) terhadap variabel Kompensasi yang menunjukkan bahwa variabel kompensasi berpengaruh signifikan. Yang berarti secara parsial dapat dinyatakan variabel Kompensasi memiliki pengaruh nyata terhadap Kinerja Karyawan di PT. Asuransi Asei Indonesia Unit Syariah Cabang Pekanbaru yang mana kenaikan ataupun penurunan yang disebabkan oleh perubahan kompensasi tersebut bersifat signifikan.

Berdasarkan analisis deskripsi variabel Kompensasi indikator bonus yang saya terima telah sesuai dengan yang diharapkan memiliki skor yang paling tinggi. Perusahaan harus memberikan bonus agar semangat kerja karyawan makin meningkat sehingga kenaikan kinerja tercapai dan tujuan perusahaan juga tercapai. Sedangkan indikator tunjangan yang diberikan perusahaan sesuai dengan posisi karyawan memiliki skor paling kecil. Perusahaan harus menyesuaikan pemberian tunjangan agar sesuai dengan posisi atau jabatan karyawan agar karyawan bisa bekerja maksimal sehingga berdampak pada kinerjanya yang bisa menguntungkan perusahaan.

Hasil penelitian ini sejalan dengan penelitian yang dilakukan oleh Arlan Adinata (2011) yang menunjukkan bahwa adanya pengaruh yang positif dan signifikan kompensasi yang diberikan terhadap kinerja karyawan. Dimana kedua penelitian ini memiliki pengaruh yang signifikan berarti dapat dinyatakan jika terjadi peningkatan atau pun penurunan pada variabel Kompensasi maka akan berdampak juga pada peningkatan atau pun penurunan terhadap Kinerja Karyawan secara signifikan.

\section{Pengaruh Lingkungan Kerja terhadap Kinerja Karyawan}

Dari hasil analisis secara deskriptif, menunjukkan bahwa Lingkungan Kerja merupakan faktor yang dianggap baik oleh responden dalam Kinerja Karyawan. Hal ini sejalan dengan hasil analisis regresi dan pengujian secara parsial (uji t) terhadap variabel Lingkungan Kerja yang menunjukkan bahwa variabel 
Lingkungan Kerja tidak signifikan. Yang berarti secara parsial dapat dinyatakan jika terjadi peningkatan atau pun penurunan pada variabel Lingkungan Kerja maka akan mempengaruhi peningkatan atau pun penurunan terhadap Kinerja Karyawan tetapi tidak signifikan.

Berdasarkan analisis deskripsi variabel Lingkungan Kerja indikator penggunaan warna ditempat bekerja tidak mengganggu suasana kerja anda memiliki skor paling tinggi. Dengan demikian tidak mengganggu karyawan dalam bekerja dan karyawan merasa nyaman sehingga karyawan dapat bekerja dengan maksimal. Sedangkan indikator ruangan kerja saya terdekorasi dengan baik memiliki skor paling kecil. Ruangan kerja yang tidak rapi akan membawa masalah terhadap kinerja karyawan. Dimana karyawan menjadi tidak nyaman bekerja sehingga tidak bisa menunjukkan kinerjanya dengan maksimal. Perlu adanya upaya perusahaan untuk selalu menjaga keasrian ruangan kerja agar karyawan merasa nyaman dan bisa bekerja secara maksimal.

Hasil penelitian ini dapat didukung dengan penelitian yang dilakukan oleh Bagus Dermawan (2012), dari hasil analisis menunjukkan bahwa adanya pengaruh positif tetapi tidak signifikan dari Lingkungan Kerja.

\section{Pengaruh Penghargaan Atas Prestasi Kerja terhadap Kinerja Karyawan}

Dari hasil analisis secara deskriptif, menunjukkan bahwa Penghargaan Atas Prestasi Kerja merupakan faktor yang dianggap cukup baik oleh responden dalam Kinerja Karyawan. Hal ini tidak sejalan dengan hasil analisis regresi dan pengujian secara parsial (uji t) terhadap variabel Penghargaan Atas Prestasi Kerja yang menunjukkan bahwa variabel Penghargaan Atas Prestasi Kerja tidak signifikan. Yang berarti secara parsial dapat dinyatakan jika terjadi peningkatan atau pun penurunan pada variabel Penghargaan Atas Prestasi Kerja maka akan mempengaruhi peningkatan atau pun penurunan terhadap Kinerja Karyawan tetapi tidak signifikan.

Berdasarkan analisis deskripsi variabel Penghargaan Atas Presatasi Kerja indikator pengawasan kerja dan penerapan sesuai SOP yang berkualitas akan meningkatkan kinerja karyawan dan perusahaan memberikan penghargaan kepada karyawan yang inovatif memiliki skor yang paling tinggi. Dengan demikian 
perusahaan tetap harus menjaga dan bahkan meningkatkan pengawasan kerja dan penerapan sesuai SOP yang berkualitas, sehingga karyawan akan merasa aman dan nyaman dalam bekerja karena sudah sesuai dengan jalurnya dan juga perusahaan memberikan penghargaan kepada karyawan yang inovatif juga bisa meningkatkan semangat kerja karyawan sehingga terjadi peningkatan kinerja karyawan. Sedangkan indicator Program pelatihan yang diberikan perusahaan menambah kesempatan karyawan untuk kemajuan karirnya memiliki skor paling kecil. Disini program pelatihan terhadap karyawan merupakan salah satu faktor penting dan sebagai penyemangat karyawan. Sehingga jika program pelatihan diberikan terhadap karyawan maka karyawan akan berusaha untuk melakukan pekerjaannya dengan baik serta mengurangi tingkat kesalahan dalam bekerja sehingga terjadi kenaikan kinerja karyawan.

Hasil penelitian ini tidak sejalan dengan penelitian yang dilakukan oleh Sinaga (2008) yang menyatakan bahwa Penghargaan memiliki pengaruh yang signifikan terhadap Kinerja Karyawan. Dimana kedua penelitian ini dapat dinyatakan jika terjadi peningkatan atau pun penurunan pada variabel Penghargaan Atas Prestasi Kerja maka akan berdampak juga pada peningkatan atau pun penurunan terhadap Kinerja Karyawan tetapi terjadi secara tidak signifikan.

\section{Pengaruh Kompensasi, Lingkungan Kerja dan Penghargaan Atas Prestasi Kerja terhadap Kinerja Karyawan}

Berdasarkan analisis regresi linier berganda yang digunakan dengan memasukkan semua unsur variabel Kompensasi, Lingkungan Kerja dan Penghargaan Atas Prestasi Kerja yang hasilnya menunjukkan adanya pengaruh terhadap Kinerja Karyawan di PT. Asuransi Asei Indonesia Unit Syariah Cabang Pekanbaru. Nilai Probabilitas yang diperoleh adalah $0,000<0,05$ dan nilai koefisien determinasi (Adjusted R Square) sebesar 0,790 yang memberikan arti bahwa besarnya kontribusi dari variabel-variabel tersebut secara bersama-sama berpengaruh terhadap kinerja karyawan sebesar $79 \%$ dan sisanya sebesar $21 \%$ dipengaruhi oleh variabel lain diluar variabel yang diteliti. Hal ini cukup memberikan keyakinan bahwa variabel-variabel independen tersebut memberikan 
pengaruh secara bersama-sama (simultan) terhadap kinerja karyawan di PT. Asuransi Asei Indonesia Unit Syariah Cabang Pekanbaru.

Hasil uji ANOVA diperoleh $\mathrm{F}$ hitung sebesar 68,520 dengan tingkat signifikan $\mathrm{F}=0,000$. Karena probabilitas yang ditunjukkan lebih kecil dari 0,05 maka model regresi dapat digunakan untuk memprediksi Kinerja Karyawan di PT. Asuransi Asei Indonesia Unit Syariah Cabang Pekanbaru. Dari hasil penelitian tersebut dapat dinyatakan bahwa kompensasi, lingkungan kerja dan penghargaan atas prestasi kerja berpengaruh signifikan terhadap kinerja karyawan di PT. Asuransi Asei Indonesia Unit Syariah Cabang Pekanbaru.

Berdasarkan analisis regresi linier berganda pada tabel 4.11 menghasilkan persamaan regresi sebagai berikut :

$$
\mathrm{Y}=0,074+0,600 \mathrm{X} 1+0,266 \mathrm{X} 2+0,105 \mathrm{X} 3
$$

Koefisien regresi untuk variabel Kompensasi (X1) adalah 0,600 Lingkungan Kerja (X2) adalah 0,266 dan Penghargaan Atas Prestasi Kerja (X3) adalah 0,105. Dimana nilai menunjukkan bahwa pengaruh variabel kompensasi, lingkungan kerja dan penghargaan atas prestasi kerja terhadap kinerja karyawan di PT. Asuransi Asei Indonesia Unit Syariah Cabang Pekanbaru adalah berpengaruh, hal ini menunjukkan bahwa setiap adanya kenaikan kompensasi, lingkungan kerja dan penghargaan atas prestasi kerja akan menyebabkan kenaikan tingkat kinerja karyawan di PT. Asuransi Asei Indonesia Unit Syariah Cabang Pekanbaru. Berdasarkan hasil analisis tersebut variabel kompensasi memiliki pengaruh yang paling kuat terhadap kinerja karyawan di PT. Asuransi Asei Indonesia Unit Syariah Cabang Pekanbaru.

Hasil penelitian ini dapat didukung dengan penelitian yang dilakukan oleh Arlan Adinata (2011), dari hasil analisis menunjukkan adanya pengaruh signifikan dari kompensasi.

\section{Kesimpulan}

Berdasarkan hasil analisis data tersebut diatas dapat diambil kesimpulan sebagai berikut :

1. Kompensasi sangat mempengaruhi kinerja karyawan. Oleh sebab itu perusahaan harus memberikan tunjangan-tunjangan agar dapat membangkitkan semangat 
kerja karyawan sehingga kinerja karyawan semakin meningkat. Berdasarkan pengujian secara parsial, hasil penelitian membuktikan bahwa variabel kompensasi berpengaruh dan signifikan terhadap variabel kinerja karyawan di PT. Asuransi Asei Indonesia Unit Syariah Cabang Pekanbaru.

2. Lingkungan kerja juga berpengaruh terhadap kinerja karyawan. Perusahaan harus menciptakan suasana kerja yang aman dan nyaman agar karyawan dapat bekerja maksimal sehingga meningkatkan kinerja karyawan. Berdasarkan pengujian secara parsial, hasil penelitian membuktikan bahwa variabel lingkungan kerja tidak berpengaruh dan tidak signifikan terhadap variabel kinerja karyawan di PT. Asuransi Asei Indonesia Unit Syariah Cabang Pekanbaru.

3. Penghargaan atas prestasi kerja juga dapat mempengaruhi kinerja karyawan. Pemberian pujian yang diberikan perusahaan terhadap karyawan bisa meningkatkan semangat kerja karyawan sehingga akan terjadi peningkatan kinerja karyawan. Berdasarkan pengujian secara parsial, hasil penelitian membuktikan bahwa variabel penghargaan atas prestasi kerja tidak berpengaruh dan tidak siginifikan terhadap variabel kinerja karyawan di PT. Asuransi Asei Indonesia Unit Syariah Cabang Pekanbaru. Tercapainya tujuan perusahaan tidak terlepas dari sumber daya manusia. Karena itu perusahaan harus memperhatikan faktor-faktor apa saja yamg dapat meningkatkan kinerja karyawan, agar karyawan dapat bekerja secara maksimal. Berdasarkan pengujian secara simultan, hasil penelitian membuktikan bahwa ketiga variabel kompensasi, lingkungan kerja dan penghargaan atas prestasi kerja berpengaruh dan signifikan terhadap variabel kinerja karyawan di PT. Asuransi Asei Indonesia Unit Syariah Cabang Pekanbaru.

\section{DAFTAR PUSTAKA}

A. A Ngurah Bagus Dermawan. 2012. Pengaruh Motivasi, Lingkungan Kerja, Kompetensi dan Kompensasi Terhadap Kepuasan Kerja dan Kinerja Pegawai di Lingkungan Kantor Dinas Pekerjaan Umum Provinsi Bali. Bali. 
A. A Prabu Mangkunegara. 2004. Manajemen Sumber Daya Manusia. PT. Remaja Rosdakarya. Bandung.

Ahmad Tohardi. 2002. Pemahaman Praktis Manajemen Sumber Daya Manusia. Universitas Tanjung Pura. Mandar Maju. Bandung.

Ahyari, Agus. 2002. Manajemen Produksi, Pengendalian Produksi : Edisi Keempat. BPFE. Yogyakarta.

Alex, S., Nitisemito. 2001. Manajemen Personalia. Ghalia Indonesia. Jakarta.

Ane Bruce, Fernando. 2008. Rahasia tempat kerja penuh semangat dan menyenangkan. Jakarta.

Arlan Adinata. 2011. Pengaruh Kompensasi Terhadap Kinerja Pegawai Dinas Pendapatan Daerah Kota Bogor. Institut Pertanian Bogor. Bogor.

Casey Fitts Hawley. 2005. 201 Cara untuk mendorong setiap karyawan berkinerja bintang. Jakarta.

Dessler, Garry. 2009. Manajemen Sumber Daya Manusia. Jakarta : Indeks.

Eka dan Subowo. 2005. Kajian Bisnis dan Manajemen. Jakarta.

G. Tyssen, Theodore. 2003. Bisnis dan Manajemen Buku Petunjuk Bagi Manajer Pemula. Alih Bahasa Hadyana Cetakan Pertama. Arcan. Jakarta.

Ghozali, Imam. 2005. Aplikasi Analisis Multivariate Dengan Program SPSS. Badan Penerbit Universitas Diponegoro. Jakarta.

Hariandja, Marihot T.E. 2002. Manajemen Sumber Daya Manusia. Grasindo. Jakarta.

Hasibuan, Malayu, S.P. 2003. Manajemen Dasar, Pengertian dan Masalah. Toko Gunung Agung. Jakarta.

Hj. Ike Kusdyah Rachmawati, SE, MM. 2008. Manajemen sumber daya manusia. Jakarta.

Ivancevich, konopaske dan Matteson. 2006. Perilaku Manajemen dan Organisasi. Alih Bahasa Gina Gania. Erlangga. Jakarta.

Kartono, Kartini. 2004. Pemimpin dan Kepemimpinan. Rajawali. Jakarta.

Manullang. 2002. Manajemen Sumber Daya Manusia : Edisi Kesebelas. Ghalia Indonesia. Jakarta.

Marihot T.E Hariandja. 2005. Manajemen Sumber Daya Manusia. Gramedia 
Widiasarana Indonesia. Jakarta.

Nawawi, Hadari. 2005. Manajemen Sumber Daya Manusia untuk Bisnis yang Kompetitif. Gajah Mada University Press. Yogyakarta.

Prawirosentono, Suyadi. 2008. Kebijakan Kinerja Karyawan : Edisi Ketiga. BPFE. Yogyakarta.

Prof. Dr. Moeheriono, M. Si. 2012. Indikator kinerja utama perencanaan, aplikasi dan pengembangan. Jakarta.

Raymond A. Noe dan John R. Hollenbeck. 2010. Manajemen sumber daya manusia mencapai keunggulan bersaing. Jakarta.

Robbins, Stephen. 2002. Prinsip-prinsip perilaku Organisasi. Erlangga. Jakarta.

Sahat Maruli Tua S. 2011. Pengaruh Tunjangan Penghasilan Terhadap Kinerja Pegawai Sekretariat Dewan Perwakilan Rakyat Daerah. Universitas Sumatera Utara. Medan.

Santoso, S. 2003. SPSS Mengolah Data Statistik Secara Profesional. Elex Media Komputindo. Jakarta.

Sedarmayanti. 2000. Restrukturisasi dan Pemberdayaan Organisasi untuk Menghadapi Dinamika Perubahan Lingkungan. Mandar Maju. Bandung.

Siagian, Sondang. 2008. Manajemen Sumber Daya Manusia. Bumi Aksara. Jakarta.

Simamora, Henry. 2004. Manajemen Sumber Daya Manusia : Edisi Ketiga Bagian Penerbitan STIE YKPN. Yogyakarta.

Sinaga. 2008. Analis Pengaruh Budaya Organisasi dan Reward Terhadap Kinerja Karyawan Pada PT. Soeloeng Laoet Medan. Universitas Sumatera Utara. Medan.

Syaifuddin Bachrun. 2012. Desain pengupahan untuk perjanjian kerja bersama. Jakarta.

Sugiyono. 2004. Metode Penelitian Bisnis. Alfabeta. Bandung.

T. Hani Handoko. 2004. Manajemen Produksi dan Operasi. BPFE. Yogyakarta.

Thoha, Miftah. 2004. Efektivitas Kerja Karyawan di Lingkungan Karyawan Negeri Sipil. LP3ES. Jakarta.

Veithzal, Rivai. 2003. Kepemimpinan dan Perilaku Organisasi. Raja Grafindo 
Relasi : Jurnal Ekonomi, Vol. 15, No. 2, July 2019, hlm. 233-262

Persada. Jakarta.

Wibowo. 2009. Manajemen Kinerja. Raja Grafindo. Jakarta. 